\title{
Opal-based isotopic proxies of paleoenvironmental conditions
}

\author{
Christina L. De La Rocha ${ }^{1}$
}

Received 24 November 2005; revised 11 May 2006; accepted 24 May 2006; published 20 September 2006.

[1] The $\delta^{30} \mathrm{Si}$ and $\delta^{15} \mathrm{~N}_{\text {diatom }}$ of diatom opal provide a view of nutrient utilization in past oceans and are used to formulate and test hypotheses concerning Southern Ocean productivity and fluctuations in atmospheric $\mathrm{CO}_{2}$ over glacial cycles. Water column profiles of the Si and $\mathrm{N}$ isotopic composition of nutrients and the $\delta^{15} \mathrm{~N}_{\text {diatom }}$ of sediment core tops support the use of $\delta^{30} \mathrm{Si}$ and $\delta^{15} \mathrm{~N}_{\text {diatom }}$ as tracers of silicic acid and nitrate utilization, but some issues remain concerning the use of these proxies for paleoceanographic reconstructions. If average marine $\delta^{30} \mathrm{Si}$ changes over time, it could contribute to the observed down core variations in $\delta^{30} \mathrm{Si}$. Reconstruction of deepwater $\delta^{30} \mathrm{Si}$ using opal from sponges or deep-dwelling radiolarians would address this concern. Cleaning and measurement methods for $\delta^{15} \mathrm{~N}_{\text {diatom }}$ need to be standardized between laboratories and in general suffer from our lack of knowledge of how much organic matter a clean diatom frustule should contain and what its $\mathrm{C} / \mathrm{N}$ ratio should be.

Corresponding shifts in the $\delta^{15} \mathrm{~N}$ and $\mathrm{C} / \mathrm{N}$ of diatom opal with species composition suggests that changes in species composition contributes to the measured down core variations in $\mathrm{N}$ and possibly $\mathrm{Si}$ as well. This could be due to changes in the ecological niche represented in the sediments or, in the case of $\mathrm{N}$, to species specific fractionation factors. Separation of opal sediments into something more closely resembling monospecific samples is a key development that needs to be made and may be possible using laminar flow systems like "split-flow lateral-transport thin fractionation"

(SPLITT). In the meantime, information on the species composition of each sieved and cleaned sample analyzed needs to be collected alongside the isotopic data.

Citation: De La Rocha, C. L. (2006), Opal-based isotopic proxies of paleoenvironmental conditions, Global Biogeochem. Cycles, 20, GB4S09, doi:10.1029/2005GB002664.

\section{Introduction}

[2] The balance between the upwelling of $\mathrm{CO}_{2}$-rich deep waters and the removal of $\mathrm{CO}_{2}$ due to the actions of phytoplankton in the Southern Ocean plays an important role in setting the atmospheric concentration of $\mathrm{CO}_{2}$ during the Quaternary [Knox and McElroy, 1984; Sarmiento and Toggweiler, 1984; Siegenthaler and Wenk, 1984; François et al., 1997; Frank et al., 2000; Sigman and Boyle, 2000; Anderson et al., 2002]. The most direct means we have of assessing this balance over glacial-interglacial cycles is the reconstruction of nutrient utilization patterns in Southern Ocean surface waters. Key to such reconstructions are two opal-based proxies, the $\mathrm{Si}$ isotopic composition of diatom opal $\left(\delta^{30} \mathrm{Si}\right)$ and the $\mathrm{N}$ isotopic composition of organic matter retained within the cell wall of diatom fossils $\left(\delta^{15} \mathrm{~N}_{\text {diatom }}\right)$. The $\delta^{30} \mathrm{Si}$ has been used to examine silicic acid utilization by diatoms and $\delta^{15} \mathrm{~N}_{\text {diatom }}$ had been used to reconstruct nitrate utilization by the phytoplankton community [De La Rocha et al., 1998; Sigman et al., 1999a;

\footnotetext{
${ }^{1}$ Alfred-Wegener-Institut für Polar und Meeresforschung, Bermerhaven, Germany.

Copyright 2006 by the American Geophysical Union. 0886-6236/06/2005GB002664
}

Brzezinski et al., 2002; Crosta and Shemesh, 2002; Crosta et al., 2005; Schneider-Mor et al., 2005].

[3] Discrimination against ${ }^{15} \mathrm{~N}$ by marine diatoms as they take up and utilize nitrate has been measured in culture and field studies to range from 2.5 to $15 \%$ [e.g., Montoya and McCarthy, 1995; Sigman et al., 1999b; Altabet and François, 2001; Needoba et al., 2003; DiFiore et al., 2006], with much of this variability due to factors, such as light level and growth rate, that affect the balance between nitrate uptake, efflux, and assimilation [Needoba and Harrison, 2004]. Diatoms also discriminate against ${ }^{30} \mathrm{Si}$ during silicic acid uptake [De La Rocha et al., 1997; Varela et al., 2004; Cardinal et al., 2005], but the range of variability in discrimination estimated, at 1.0 to $1.5 \%$, is small.

[4] The fractionation of $\mathrm{Si}$ and $\mathrm{N}$ isotopes during nutrient uptake results in an increase, through Rayleigh distillation, of $\delta^{30} \mathrm{Si}$ and $\delta^{15} \mathrm{~N}$ of silicic acid and nitrate in the euphotic zone as phytoplankton draw the nutrient concentrations down during a bloom or other period of growth. This rise in nutrient $\delta^{30} \mathrm{Si}$ and $\delta^{15} \mathrm{~N}$ with nutrient depletion should be recorded in the opal produced by growing diatoms. High values of $\delta^{30} \mathrm{Si}$ and $\delta^{15} \mathrm{~N}$ in sedimentary diatoms are thus taken to indicate that a greater fraction of available nutrients has been consumed over the course of a growing season [Altabet and François, 1994; De La Rocha et al., 1997, 2000a; Sigman et al., 1999b; Wischmeyer et al., 2003; 


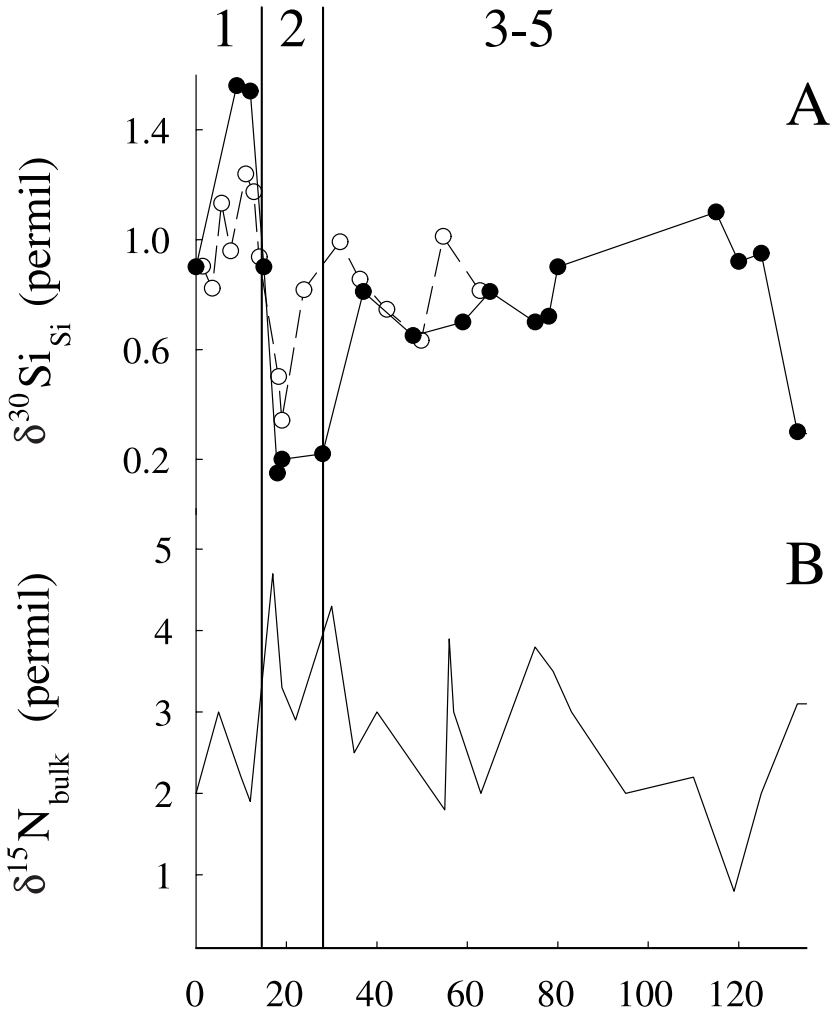

Age (kyr)

Figure 1. Opal-based records from Southern Ocean sediment core, RC13-259 (53 $\left.{ }^{\circ} 53^{\prime} \mathrm{S}, 4^{\circ} 56^{\prime} \mathrm{W} ; 2677 \mathrm{~m}\right)$. (a) Solid circles: $\delta^{30} \mathrm{Si}$ record going back two full glacial cycles (data are replotted from Brzezinski et al. [2002]); open circles: the shorter record of De La Rocha et al. [1998] from the nearby core, $\mathrm{RC} 13-269\left(52^{\circ} 38^{\prime} \mathrm{S}, 00^{\circ} 08^{\prime} \mathrm{W} ; 2,591 \mathrm{~m}\right)$. (b) The $\delta^{15} \mathrm{~N}$ of bulk sediments [Brzezinski et al., 2002] from RC13-259. Marine Isotope Stages 1, 2, and 3-5 are identified at the top of the plot.

Varela et al., 2004; Cardinal et al., 2005; De La Rocha and Bickle, 2005].

[5] Although the distribution and behavior of $\mathrm{Si}$ and $\mathrm{N}$ isotopes in the ocean should have been studied through fieldwork and modeling, and there have been several culturing-based studies to quantify isotope fractionation, there remains much to learn about how well the sedimentary records of $\delta^{15} \mathrm{~N}_{\text {diatom }}$ and $\delta^{30} \mathrm{Si}$ track nutrient utilization in the euphotic zone. The impacts of diagenesis and of variations in the diatom species present in the sediments on the signal reconstructed have not been deeply investigated. In addition, cleaning and analytical methods for $\delta^{15} \mathrm{~N}_{\text {diatom, }}$ which seem to have a sizable impact on the value measured [Robinson et al., 2004], differ considerably between labs.

[6] All of these problems are standard growing pains for maturing paleoceanographic proxies. Even the enormously successful foraminifera-based proxies, $\delta^{13} \mathrm{C}$ and $\delta^{18} \mathrm{O}$, faced such issues [e.g., Shackleton et al., 1973; Spero and Lea, 1996] and emerged honed into the indispensable tools that they are today. The more we learn about the complications involved with stable isotopic signals in biogenic opal, the better we shall be able to wield these tools for paleoenvironmental reconstructions.

[7] Even at this relatively unrefined stage of their development as proxies, $\delta^{15} \mathrm{~N}_{\text {diatom }}$ and $\delta^{30} \mathrm{Si}$ are being used as the basis for the formulation, testing, and refinement of hypotheses of the drivers of atmospheric $\mathrm{CO}_{2}$ change over Quaternary glacial cycles [e.g., François et al., 1997; De La Rocha et al., 1998; Sigman and Boyle, 2000; Anderson et al., 2002; Sarmiento et al., 2004]. The importance of understanding the causes of glacial-interglacial $\mathrm{CO}_{2}$ changes underscores the need for us to better understand the signals they are recording. This manuscript reviews conclusions drawn from $\delta^{15} \mathrm{~N}_{\text {diatom }}$ and $\delta^{30} \mathrm{Si}$ about nutrient dynamics in the Southern Ocean over glacial-interglacial cycles, investigates whether or not the interpretations of the records are justified, identifies the most significant potential pitfalls with the use of these proxies, and makes recommendations for future paleoceanographic studies using $\delta^{15} \mathrm{~N}_{\text {diatom }}$ and $\delta^{30} \mathrm{Si}$.

\section{Reconstructions of Southern Ocean Paleoceanography From $\delta^{30} \mathrm{Si}$ and $\delta^{15} \mathrm{~N}$}

[8] Variations in marine diatom $\delta^{30} \mathrm{Si}$ from Southern Ocean sediments south of the present-day Antarctic Polar Front (APF) (e.g., Figure 1a) range by $\sim 1 \%$ over a glacial cycle, with minimum values occurring at the Last Glacial Maximum (LGM) [De La Rocha et al., 1998; Brzezinski et al., 2002]. This pattern of high interglacial and low glacial values carries back through at least several glacial cycles [Brzezinski et al., 2002] and is thought to indicate a lesser extent of silicic acid utilization during the glacials, especially during times of maximal sea ice cover [De La Rocha et al., 1998] and increased Fe availability [Brzezinski et al., 2002]. Increased sea ice coverage of the Southern Ocean would lower overall levels of silicic acid uptake by inhibiting the growth of diatoms in the water column [Chase et al., 2003]. A release from $\mathrm{Fe}$ limitation during glacial times could lower silicic acid utilization by lowering the $\mathrm{Si}$ :C and $\mathrm{Si}: \mathrm{N}$ ratios of growing diatoms [Hutchins and Bruland, 1998; Takeda, 1998; De La Rocha et al., 2000b; Franck et al., 2003] (Table 1).

[9] In direct opposition to the suggestion of lower glacial nutrient utilization of $\delta^{30} \mathrm{Si}$ are records of $\delta^{15} \mathrm{~N}_{\text {diatom }}$ from the high opal belt south of the APF. On the basis of the results from about a dozen cores [Sigman et al., 1999a; Crosta and Shemesh., 2002; Shemesh et al., 2002; Crosta et al., 2005; Schneider-Mor et al., 2005], and influenced by

Table 1. Cleaned Diatom Opal Contents

\begin{tabular}{cccc}
\hline Element & $\mu$ g Per mg Opal & $\mu$ mol Per mg Opal & Weight Percent \\
\hline $\mathrm{Si}$ & 440 & 15 & 44 \\
$\mathrm{O}^{\mathrm{a}}$ & 510 & 30 & 51 \\
$\mathrm{C}$ & 2.5 & 0.21 & 0.25 \\
$\mathrm{~N}$ & 0.3 & 0.02 & 0.03 \\
\hline
\end{tabular}

${ }^{\mathrm{a}}$ This is structural $\mathrm{O}$, not that from associated $\mathrm{OH}$ or $\mathrm{H}_{2} \mathrm{O}$. 


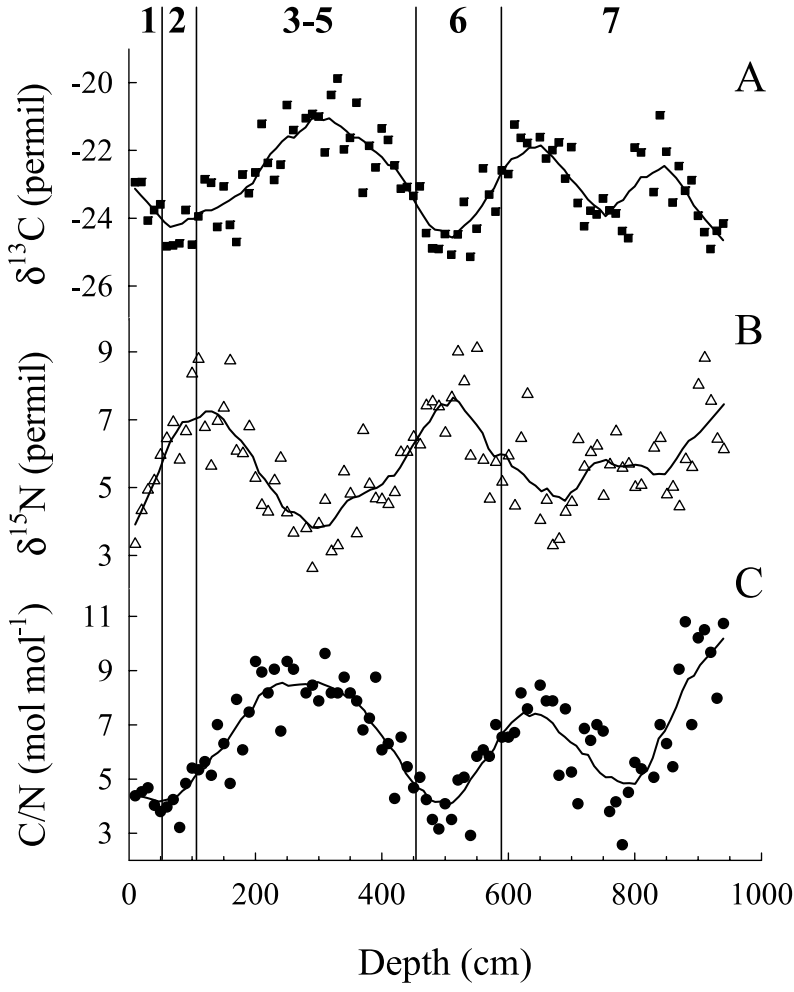

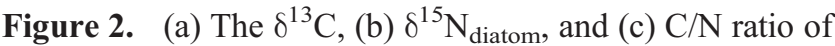
diatom silica organic matter from Southern Ocean sediment core, SO136-11 (56 $\left.40^{\prime} \mathrm{S}, 160^{\circ} 14^{\prime} \mathrm{E}, 3912 \mathrm{~m}\right)$. Data are replotted from Crosta et al. [2002] and Crosta and Shemesh [2002]. Marine Isotope Stages 1, 2, 3-5, 6, and 7 are identified at the top of the plot. With respect to the $\delta^{15} \mathrm{~N}$ and $\mathrm{C} / \mathrm{N}$ values, it should be noted these samples were cleaned with nitric acid.

the results from bulk sediments [François et al., 1997], the prevailing notion is that glacial values of $\delta^{15} \mathrm{~N}_{\text {diatom }}$ are higher than interglacial values (Figure $2 b$ ), indicating more complete consumption of nitrate stocks by phytoplankton during glacials [Sigman et al., 1999a; Crosta and Shemesh, 2002]. In some cores $\delta{ }^{15} \mathrm{~N}_{\text {diatom }}$ also varies inversely with the $\mathrm{C}$ isotopic composition and $\mathrm{C} / \mathrm{N}$ ratio of that same organic matter (Figure 2) [Crosta and Shemesh, 2002; Crosta et al., 2002]. However, not all published cores show higher $\delta^{15} \mathrm{~N}_{\text {diatom }}$ values consistently at glacial maxima (Figure 3) [Shemesh et al., 2002; Crosta et al., 2005; Schneider-Mor et al., 2005], nor do they all show the strong anticorrelation between $\delta^{15} \mathrm{~N}_{\text {diatom }}$ and $\delta^{13} \mathrm{C}_{\text {diatom }}$ [Crosta et al., 2005; Schneider-Mor et al., 2005].

[10] From the Subantarctic Zone, there are currently only three published $\delta^{15} \mathrm{~N}_{\text {diatom }}$ records [Crosta et al., 2005; Robinson et al., 2005] and no published records of diatom $\delta^{30} \mathrm{Si}$. The two cores in the Indian Sector (MD88-769 and MD84-527) were measured by two different methods, but both show $\delta^{15} \mathrm{~N}_{\text {diatom }}$ values that, over the last $30-40 \mathrm{kyr}$, range between about 1 and $6 \%$. The pattern of variations differs, however, between the two cores. The $\delta^{15} \mathrm{~N}_{\text {diatom }}$ in the core analyzed via persulfate oxidation is highest during the glacial and shows lowest values during Marine Isotope Stage 1 [Robinson et al., 2005]. The core measured by the more traditional method of combustion in an elemental analyzer shows no great systematic differences between the Holocene and last glacial [Crosta et al., 2005].

[11] The opposing signals of $\delta^{30} \mathrm{Si}$ and $\delta^{15} \mathrm{~N}_{\text {diatom }}$ in Southern Ocean sediment cores suggest that the cycles of $\mathrm{Si}$ and $\mathrm{N}$ in the Southern Ocean are more dynamic, relative to each other, over glacial-interglacial cycles than originally anticipated. At first it seemed unlikely that an LGM peak in nitrate consumption by the whole phytoplankton community could occur concurrently with a minimum in silicic acid utilization by diatoms in a part of the world where primary production is dominated by diatoms. However, $\mathrm{Si}$ and $\mathrm{N}$ cycling could be decoupled over glacial-interglacial timescales if the bulk of nitrate uptake during glacials is done, not by diatoms, but by nonsiliceous phytoplankton [De La Rocha et al., 1997; Anderson et al., 2002] such as Phaeocystis. Alternatively, the glacial increase in Fe availability in the Southern Ocean could increase diatom utilization of nitrate while diminishing diatom uptake of silicic acid [Brzezinski et al., 2002] in keeping with the observation that low availability of $\mathrm{Fe}$ pushes the $\mathrm{Si}$ N uptake ratio of diatoms up to $\sim 4 \mathrm{~mol} \mathrm{~mol}^{-1}$ from nutrient replete levels of $1 \mathrm{~mol} \mathrm{~mol}^{-1}$ [Hutchins and Bruland, 1998; Takeda, 1998; De La Rocha et al., 2000b; Franck et al., 2003].

[12] Although work is still being done to understand the roughly opposite patterns of $\delta^{30} \mathrm{Si}$ and $\delta^{15} \mathrm{~N}$ (both bulk and diatom) in Southern Ocean sediments, these proxies are being used to understand the paleoceanography of the Southern Ocean and its relationship to atmospheric levels of $\mathrm{CO}_{2}$. High values of both bulk sediment and diatom $\delta^{15} \mathrm{~N}$ suggesting high levels of nitrate utilization in the Southern Ocean at the LGM coinciding with indications for decreased rates of export production have been interpreted as indicat-

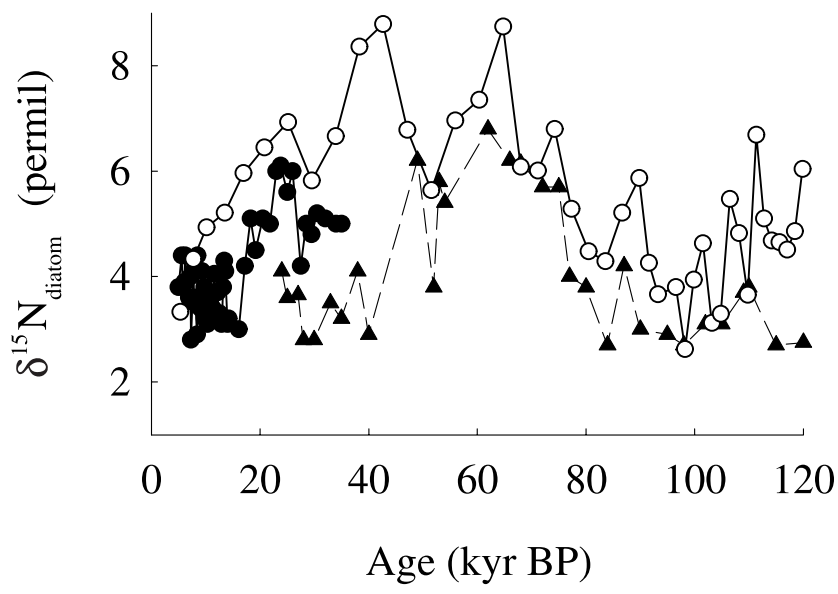

Figure 3. The $\delta^{15} \mathrm{~N}_{\text {diatom }}$ from three cores with age models from south of the present-day Antarctic Polar Front. Core SO136-111 from the Indian Sector $\left(56^{\circ} 40 \mathrm{~s}, 160^{\circ} 14^{\prime} \mathrm{E}\right)$ [Crosta and Shemesh, 2002] is shown by open circles. ODP site $1094\left(53^{\circ} 10.8^{\prime} \mathrm{S}, 5^{\circ} 7.8^{\prime} \mathrm{E}\right)$ [Schneider-Mor et al., 2005] and core TN057-13-PC4 $\left(53.2^{\circ} \mathrm{S}, 5.1^{\circ} \mathrm{E}\right)$ [Shemesh et al., 2002] from the Atlantic Sector are shown by solid triangles and solid circles, respectively. 


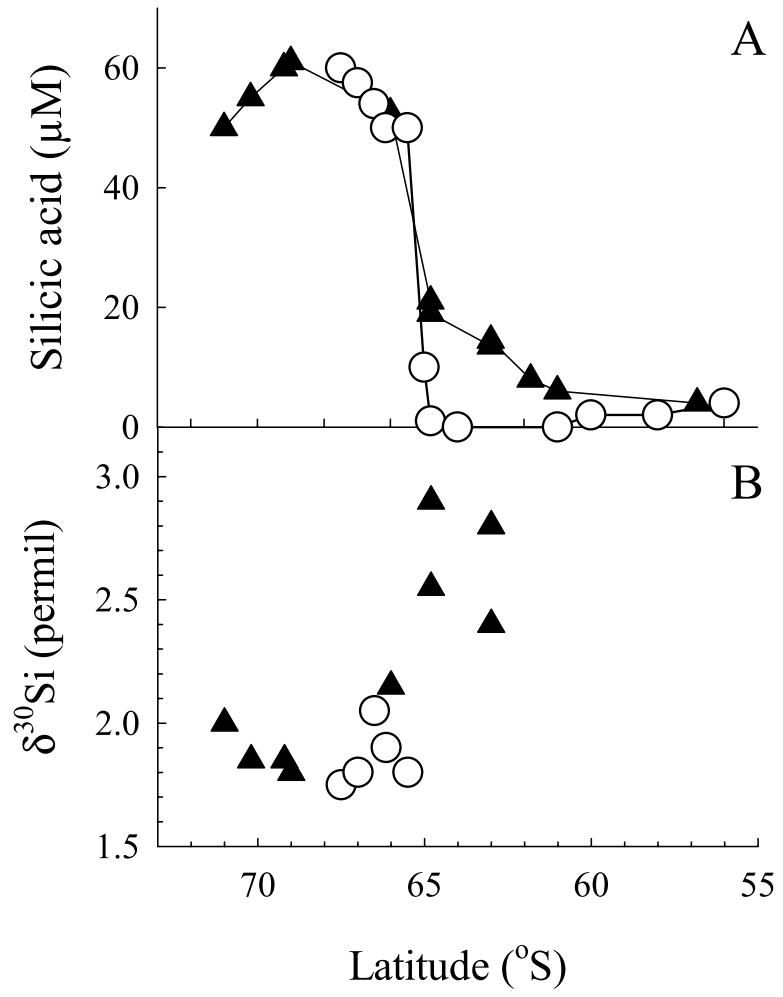

Figure 4. (a) Silicic acid concentration and (b) $\delta^{30} \mathrm{Si}$ of surface water samples along a transect at $170^{\circ} \mathrm{W}$ (replotted from Varela et al. [2004]). Solid triangles are samples taken in February-March 1998, and open circles are samples collected during January 1998.

ing reduced rates of deepwater and $\mathrm{CO}_{2}$ ventilation from the Southern Ocean during glacial times [François et al., 1997; Sigman and Boyle, 2000]. Shifts in silicic acid to nitrate utilization ratios in diatoms as levels of $\mathrm{Fe}$ availability fluctuate [Hutchins and Bruland, 1998; Takeda, 1998; De La Rocha et al., 2000b; Franck et al., 2003] combined with $\delta^{30} \mathrm{Si}$ and $\delta^{15} \mathrm{~N}$ records have been used to suggest that $\mathrm{Fe}$ fertilization of the glacial Southern Ocean has far-reaching effects on the biological pump by shifting the nitrate to silicic acid ratio of nutrients exported to lower latitude upwelling zones [Sarmiento et al., 2004].

\section{Evidence Supporting the Use of $\delta^{30} \mathrm{Si}$ and $\delta^{15} \mathrm{~N}$ as Proxies}

[13] Although diatoms in culture are known to fractionate both $\mathrm{Si}$ and $\mathrm{N}$ isotopes, pushing up the $\delta^{30} \mathrm{Si}$ and $\delta^{15} \mathrm{~N}$ of silicic acid and nitrate as nutrient concentrations are diminished [Montoya and McCarthy, 1995; De La Rocha et al., 1997; Needoba et al., 2003], this is, on its own, not sufficient support for the use of $\delta^{30} \mathrm{Si}$ and $\delta^{15} \mathrm{~N}_{\text {diatom }}$ as nutrient utilization proxies. Also, because it is difficult to clean cultured diatoms of cytoplasmic organic matter prior to measurement of diatom cell wall $\delta^{15} \mathrm{~N}$ (i.e. $\delta^{15} \mathrm{~N}_{\text {diatom }}$ ), no measurement of $\mathrm{N}$ isotope fractionation has been made between nitrate and diatom cell wall organic matter. In any case, confidence in the proxies requires studies of isotope and nutrient cycling in the water column, or connected to sedimentary materials from sediment traps or core tops. There are several such studies that have been carried out.

\subsection{Behavior of Silicon Isotopes in Diatom-Dominated Systems}

[14] The distribution of silicon isotopes in the oceans can be used as a test of $\delta^{30} \mathrm{Si}$ as a proxy for silicic acid utilization. If isotope fractionation during silicic acid utilization by diatoms in the euphotic zone controls the $\delta^{30} \mathrm{Si}$ of surface waters and of sinking biogenic opal, the $\delta^{30} \mathrm{Si}$ of silicic acid should be highest where diatom growth has drawn down silicic acid concentrations to low levels [Wischmeyer et al., 2003]. Because diatoms utilize nearly all of the silicic acid in the euphotic zone, the $\delta^{30} \mathrm{Si}$ of deep ocean silicic acid and that of opal accumulating on the seafloor should be identical to each other and to the average ${ }^{30} \mathrm{Si}$ of external inputs of silicic acid to the ocean [De $\mathrm{La}$ Rocha and Bickle, 2005].

[15] Although there have not been many studies of the $\delta^{30} \mathrm{Si}$ of seawater silicic acid or of modern sediments, some general patterns have emerged. These patterns fall in accordance with predictions based on models of silica cycling, ocean circulation, and isotope fractionation [Wischmeyer et al., 2003; De La Rocha and Bickle, 2005]. The highest $\delta^{30} \mathrm{Si}$ values of silicic acid are generally found in surface waters [De La Rocha et al., 2000a; Varela et al., 2004; Cardinal et al., 2005]. The $\delta^{30} \mathrm{Si}$ of silicic acid in deep waters is on the order of $+0.9 \%$ [De La Rocha et al., 2000a], comparing well with samples of riverine silicic acid $(+0.4$ to $+1.2 \%$ [De La Rocha et al., 2000a]), high values from the Yangtze River [Ding et al., 2004] aside. Biogenic silica from Southern Ocean sediments and sediment traps and from Rhizosolenia mats from the North Pacific central gyre have $\delta^{30} \mathrm{Si}$ values ranging from +0.7 to $+1.9 \%$ [ [De La Rocha et al., 2000a; Varela et al., 2004], values similar to those of rivers and deep waters.

[16] Three studies of the $\delta^{30} \mathrm{Si}$ of silicic acid in surface samples also support the idea that diatom uptake of silicic acid pushes $\delta^{30}$ Si upward. Water samples from one euphotic zone profile in the Monterey Bay (California) and from two in the Southern Ocean show that the $\delta^{30} \mathrm{Si}$ (or $\delta^{29} \mathrm{Si}$ ) of silicic acid increases surfaceward from the seasonal thermocline as silicic acid concentrations decrease due to diatom growth [De La Rocha et al., 2000a; Varela et al., 2004; Cardinal et al., 2005]. In addition, the two Southern Ocean studies observed the rise expected in the $\delta^{30} \mathrm{Si}$ (or ${ }^{29} \mathrm{Si}$ ) of surface waters with the drop in $\mathrm{Si}$ concentrations toward the Antarctic Polar Front (Figure 4) [Varela et al., 2004; Cardinal et al., 2005].

[17] These $\delta^{30} \mathrm{Si}$ data can be combined with silicic acid concentrations to estimate fractionation factors from the water column samples and compare them to the results from culturing experiments. Nutrient and isotope profiles can be used to estimate isotope fractionation associated with biological uptake from the euphotic zone based on a closed system model (assuming one pulse of Si delivered into the euphotic zone prior to biological uptake) [Mariotti et al., 


\section{$\delta^{30} \mathrm{Si}($ permil)}

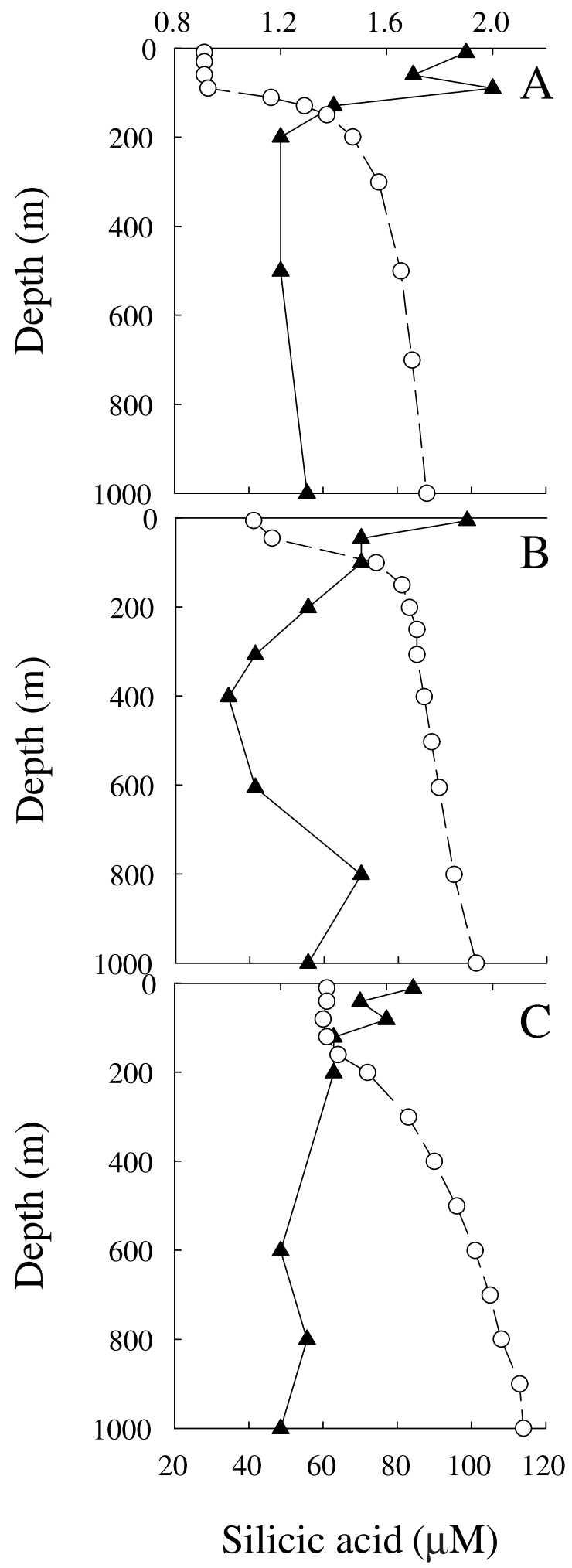

1981; De La Rocha et al., 2000a] or an open system model (more continuous delivery of $\mathrm{Si}$ into the euphotic zone) [Barford et al., 1999; Sigman et al., 1999b; Varela et al., 2004]. There is a general agreement between fractionation factors measured in the laboratory and those estimated from field samples, lending strong support for the use of $\delta^{30} \mathrm{Si}$ to reconstruct $\mathrm{Si}$ utilization in the past. Culture experiments suggest that diatoms produce silica that is -1.1 to $-1.5 \%$ o [De La Rocha et al., 1997; Milligan et al., 2004] relative to the silicic acid source. These results are identical to estimates from the Monterey Bay data [De La Rocha et al., 2000a] of $-1.1 \%$ o (closed system) to -1.5 (open system). This estimate lies in close agreement the $-1.0 \%$ (closed) to $-1.7 \%$ o (open) estimated by Varela et al. [2004] in the Pacific Sector of the Southern Ocean. Likewise, the three sites in another study from the Pacific Sector [Cardinal et $a l ., 2005]$ that showed depletion of $\mathrm{Si}$ in the euphotic zone following spring and summer growth of diatoms (Figure 5) yield fractionation factors around $-1 \%$.

\subsection{Water Column, Sediment Trap, and Core Top Evidence in Support of $\delta^{15} \mathbf{N}_{\text {diatom }}$ as a Nitrate Utilization Proxy}

[18] Measurements of the concentration and $\delta^{15} \mathrm{~N}$ of nitrate in the Southern Ocean suggest that nitrate utilization by phytoplankton controls the $\delta^{15} \mathrm{~N}$ of nitrate in the euphotic zone [Sigman et al., 1999b; Altabet and François, 2001; Lourey et al., 2003]. The $\delta^{15} \mathrm{~N}$ of nitrate has been seen to increase as nitrate concentrations drop across the Antarctic Polar Front to the Subantarctic Zone [Sigman et al., 1999b; Lourey et al., 2003]. The $\delta^{15} \mathrm{~N}$ of nitrate in the Southern Ocean has also been observed to increase seasonally by several per mil as nitrate concentrations dropped owing to biological utilization [Altabet and François, 2001; Lourey et al., 2003]. Last, vertical profiles of $\delta^{15} \mathrm{~N}$ of nitrate show their highest $\delta^{15} \mathrm{~N}$ values with the seasonal depletion of nitrate in the surface mixed layer [Altabet and François, 2001]. Fractionation factors estimate from these nitrate data suggest that phytoplankton discriminate against ${ }^{15} \mathrm{~N}$ by roughly 4 to $10 \%$.

[19] There have been no studies on the $\delta^{15} \mathrm{~N}_{\text {diatom }}$ of sinking or suspended matter in the ocean. The closest studies have come to this is to look at seasonal and depthrelated variability in the $\delta^{15} \mathrm{~N}$ of particulate nitrogen in general. What these studies suggest is that bulk sediments are not the most suitable material for $\mathrm{N}$ isotope-based reconstructions of nitrate uptake and that organic material protected from microbial alteration (e.g., that occluded

Figure 5. Plots of silicic acid concentration (open circles) and $\delta^{30} \mathrm{Si}$ (solid triangles) from Southern Ocean sites from a transect along $140^{\circ} \mathrm{E}$ at (a) $60^{\circ} 48^{\prime} \mathrm{S}$, (b) $63^{\circ} 54^{\prime} \mathrm{S}$, and (c) $64^{\circ} 54^{\prime} \mathrm{S}$. These data, which were measured as $\delta^{29} \mathrm{Si}$ [Cardinal et al., 2005], have been converted to $\delta^{30} \mathrm{Si}$ by multiplication by 1.93 [De La Rocha, 2002]. Closed and open system estimates of fraction factors from the upper $\sim 200 \mathrm{~m}$ of the 3 plots are -0.7 and $-1.1 \%$ for Figure $5 \mathrm{a}$, -0.5 and $-0.6 \%$ for Figure $5 b$, and -1.3 and $-1.6 \%$ for Figure 5c, respectively. 
within the matrix of diatom silica) may be the best option for reconstructions of $\delta^{15} \mathrm{~N}$.

[20] The $\delta^{15} \mathrm{~N}$ of suspended and sinking particulate nitrogen in the Southern Ocean does not clearly follow the patterns of nitrate utilization in surface waters. Suspended particulate nitrogen in the Southern Ocean has a lower $\delta^{15} \mathrm{~N}$ than would be expected from levels of nitrate depletion [Lourey et al., 2003], and the $\delta^{15} \mathrm{~N}$ of sinking particulate nitrogen is at its highest value in winter, the time of the lowest levels of nitrate utilization [Altabet and François, 2001; Lourey et al., 2003]. It has been argued that the decoupling of sinking particulate nitrogen $\delta^{15} \mathrm{~N}$ from surface nitrate utilization is largely due to $\mathrm{N}$ isotope fractionation during the remineralization of organic matter [Lourey et al., 2003]. The enrichment of sinking particles in ${ }^{15} \mathrm{~N}$ due to such diagenesis during transit to the seafloor is large, on the order of the glacial-interglacial variations observed in the bulk sediment $\delta^{15} \mathrm{~N}$ record, arguing against the use of bulk sediment $\delta^{15} \mathrm{~N}$ for paleoceanographic reconstructions. The $\mathrm{N}$ occluded within the silica of diatom frustules is thought to be protected from this kind of alteration [Sigman et al., 1999a], arguing for the use of $\delta^{15} \mathrm{~N}_{\text {diatom instead of }}$ bulk sediment $\delta^{15} \mathrm{~N}$.

[21] A transect of sediment multicore tops through the Antarctic Polar Front in the Indian Sector of the Southern Ocean provides direct evidence in support of the use of $\delta^{15} \mathrm{~N}_{\text {diatom }}$ as a nutrient utilization proxy. Low values of $\delta^{15} \mathrm{~N}_{\text {diatom }}$ are encountered at higher latitudes, where nitrate concentrations are high in surface waters [Sigman et al., 1999a]. The $\delta^{15} \mathrm{~N}_{\text {diatom }}$ values rise by $3-4 \%$ o to the north as nitrate concentrations drop, in keeping with the notion that biological utilization of nitrate pushes the $\delta^{15} \mathrm{~N}$ of surface waters and diatoms toward higher values due to Rayleigh distillation.

\section{Secular Variations in Whole Ocean $\delta^{30} \mathrm{Si}$ and $\delta^{15} \mathbf{N}$}

[22] Comparison of surface water, suspended particle, sediment trap, and sediment core top values of the $\delta^{30} \mathrm{Si}$ and $\delta^{15} \mathrm{~N}$ of diatoms, silicic acid, and/or nitrate have been a successful step in improving confidence in the use of these isotopes as nutrient utilization proxies. These studies, however, revolve around processes as they occur in the modern ocean and over short timescales. There are other questions that must be addressed to improve our confidence in $\delta^{30} \mathrm{Si}$ and $\delta^{15} \mathrm{~N}_{\text {diatom }}$ over the glacial-interglacial cycles of the Quaternary. These questions largely revolve around what other effects than nutrient depletion could be contributing to the observed down core variations in $\delta^{30} \mathrm{Si}$ and $\delta^{15} \mathrm{~N}_{\text {diatom. }}$. Changes in the species composition of the sediments being analyzed, artifacts introduced by cleaning and analytical procedures, and secular variations in the average $\delta^{30} \mathrm{Si}$ and $\delta^{15} \mathrm{~N}$ of seawater are the three main causes of concern.

[23] The issue with the greatest potential to confound $\delta^{30} \mathrm{Si}$ as a proxy for paleonutrient utilization is the possibility that the average $\delta^{30} \mathrm{Si}$ of seawater silicic acid changes over time. The oceanic residence time of $\mathrm{Si}$ is roughly 15,000 years [Tréguer et al., 1995] and a full glacialinterglacial cycle covers over 100,000 years. Some portion of the $\sim 1 \% \delta^{30} \mathrm{Si}$ down core signal could easily be due to changes in the whole ocean average $\delta^{30} \mathrm{Si}$.

[24] In a world where diatoms convert almost all the silicic acid in surface waters to opal, the average $\delta^{30} \mathrm{Si}$ of seawater $\mathrm{Si}$ should be equal to the average $\delta^{30} \mathrm{Si}$ of the $\mathrm{Si}$ inputs to the ocean [De La Rocha and Bickle, 2005]. Currently, $85 \%$ of the inputs come via rivers [Tréguer et al., 1995] and the approximately $+1 \%$ average $\delta^{30} \mathrm{Si}$ of ocean waters [De La Rocha et al., 2000a] suggests that the average riverine $\delta^{30} \mathrm{Si}$ should be $+1.2 \%$ to offset the $-0.3 \%$ signature of hydrothermal vent fluids. The $\delta^{30} \mathrm{Si}$ range seen so far for rivers is +0.4 to $+3.4 \%$. [De La Rocha et al., 2000a; Ding et al., 2004].

[25] Weathering "intensity" (the fraction of Si weathered from primary minerals that becomes locked up in secondary minerals such as clays versus delivered to ground and river waters) is a likely candidate for the control of river $\delta^{30} \mathrm{Si}$ [De La Rocha et al., 2000a; Ziegler et al., 2005]. The formation of siliceous cements may also drive up the $\delta^{30} \mathrm{Si}$ of groundwaters [Basile-Doelsch et al., 2005]. Alternatively, the cycling of $\mathrm{Si}$ through terrestrial biogenic silica pools may also impact $\delta^{30} \mathrm{Si}$, as it has been modeled to have an impact on Ge/Si [Derry et al., 2005]. These proposed mechanisms all have rates that respond to climatic conditions, and hence climate change may result in a shift in the long term average $\delta^{30} \mathrm{Si}$ of seawater.

[26] The most direct way to determine if secular variations in whole ocean $\delta^{30} \mathrm{Si}$ affect reconstructions of silicic acid utilization over glacial cycles would be to put together a record of deep water $\delta^{30} \mathrm{Si}$. Since deep waters contain high concentrations of silicic acid and play host to relatively little silica production, they are never put through the nutrient depletion and Rayleigh distillation that control the $\delta^{30} \mathrm{Si}$ of euphotic zone silicic acid. Either siliceous deep sea sponges or deep dwelling radiolarians could be used to track the average $\delta^{30} \mathrm{Si}$ of deepwater [De La Rocha, 2003]. The main obstacles to this are that fractionation of silicon isotopes by sponges is large and variable, and that it would be difficult to separate out small, deep-dwelling radiolarians from the rest of the sediment.

[27] Although the residence time of fixed $\mathrm{N}$ in the ocean is quite short (2-3 kyr) [Brandes and Devol, 2002] relative to glacial-interglacial cycles, the question of secular variations in the $\delta^{15} \mathrm{~N}$ of seawater nitrate over glacial-interglacial cycles is one that has been resolved. The $\delta^{15} \mathrm{~N}$ of bulk sediments in regions where nutrients are completely consumed and denitrification does not occur in the water column should reflect the $\delta^{15} \mathrm{~N}$ of nitrate upwelled into the surface (diagenetic offsets aside). Such records from the South China Sea over the last 200,000 years show steady baselines and no significant variation with climate, suggesting that the average $\delta^{15} \mathrm{~N}$ of seawater nitrate has remained steady over the last few glacial cycles [Kienast, 2000].

\section{Analytical Issues}

\subsection{Trouble With Cleaning Methods}

[28] Most $\delta^{15} \mathrm{~N}$ data for sediments, even in the opal-rich Southern Ocean, come from bulk sediments [Altabet and François, 1994; François et al., 1997; Brzezinski et al., 


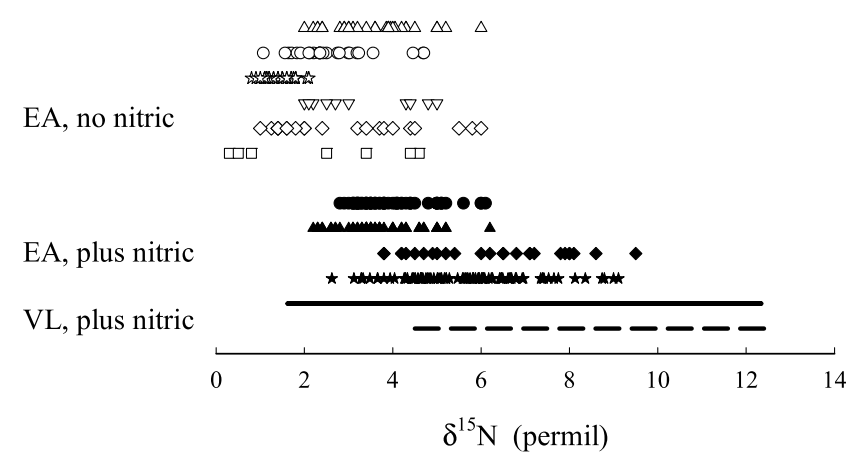

Figure 6. The $\delta^{15} \mathrm{~N}_{\text {diatom }}$ from Southern Ocean sediment cores within the last 30 to $130 \mathrm{kyr}$ measured using different analytical and cleaning methods. Samples are clustered by measurement procedure: cleaning without nitric acid and use of elemental analyzer, cleaning with nitric and use of EA, and cleaning with nitric and use of vacuum line. Open up triangles, core MD88-769 [Crosta et al., 2005]; open circles, 1786-1 (H. Jacot Des Combes, unpublished data, 2005); open stars, NBP96-4-2; open down triangles, KTB 13; open diamonds, AII 102-22; open squares, MD84-552 [Sigman et al., 1999a]. Solid down triangles are ODP site 1094 [Schneider-Mor et al., 2005], and solid circles are the nearby core, TN057-13-PC4 [Shemesh et al., 2002]. Solid up triangles are core IO 1277-10, and solid stars are SO136-111 [Crosta and Shemesh, 2002]. Solid diamonds are MD97-2101 (from the present-day subantarctic zone) [Crosta et al., 2005]. The solid line is RC13-259 [Singer, 1994], and the dashed line is RC13-271 [Shemesh et al., 1993].

2002]. The interpretation of the $\delta^{15} \mathrm{~N}$ of such bulk fossil organic matter is complicated by variability in its source (phytoplankton, animals, and bacteria), chemical composition, and state of preservation. The $\delta^{15} \mathrm{~N}$ of different organisms is also quite variable, as is the $\delta^{15} \mathrm{~N}$ of different compounds within a single organism [Macko et al., 1987], owing to isotopic fractionation at various steps in biosynthetic pathways. Likewise, the $\delta^{15} \mathrm{~N}$ of particulate organic matter shifts during zooplankton consumption and microbial decomposition of the organic matter [Saino and Hattori, 1980], either through the preferential decomposition of one compound versus another, or through processes directly involving isotope fractionation.

[29] These problems can be minimized by analyzing specific compounds somewhat resistant to degradation and whose degree of preservation is quantifiable. It has thus been a natural step to move from the analysis of bulk sedimentary $\delta^{15} \mathrm{~N}$ to that of trace quantities of organic matter present within the silicified cell wall of diatoms [Shemesh et al., 1993; Sigman et al., 1999a]. Although there is interspecific variability to the organic compounds present in the cell wall [Kröger et al., 2000], this approach at least narrows down the analyzed organic matter from the hodge-podge present in bulk sediments to that produced only for the construction of the diatom cell wall. This organic matter, encapsulated within the siliceous cell wall, may also be protected from decomposition by microbes and zooplankton [Sigman et al., 1999a].

[30] The amount of organic matter $\mathrm{N}$ encapsulated within the fossil frustules is only 0.014 to 0.035 weight $\%$ of the frustule [Sigman et al., 1999a; Robinson et al., 2004]. This means that opal samples must be both large (up to $100 \mathrm{mg}$ ) and carefully cleaned of cytoplasm and other organic matter and detritus.

[31] There has never been one method settled on for the cleaning of the opal for measurement of $\delta^{15} \mathrm{~N}$. Some studies used a 1:1 mixture of perchloric acid and concentrated nitric acid [Crosta and Shemesh, 2002; Schneider-Mor et al., 2005], some perchloric acid plus concentrated hydrochloric acid [Sigman et al., 1999a], and others 30\% hydrogen peroxide on its own [Robinson et al., 2004]. Southern Ocean sediment cores cleaned with a mixture of perchloric and nitric acids have $\delta^{15} \mathrm{~N}$ values of +2 to either +7 or $+10 \%$ (depending on the core) when measured via combustion in an elemental analyzer, and from +2 to $+13 \%$ when analyzed through combustion in a vacuum line (Figure 6). Samples cleaned using perchloric or peroxide treatments without nitric acid yield samples with values ranging from 0 to $+6 \%$.

[32] The variability in $\delta^{15} \mathrm{~N}$ with the cleaning method is due to some combination of contamination from nitric acid, incomplete cleaning of the frustules, and partial decomposition of the organic matter within the silica matrix of the samples. When measured via combustion in an elemental analyzer, sedimentary diatom opal cleaned with perchloric plus nitric acid contains 0.05 to 1.0 weight $\% \mathrm{~N}$ [e.g., Crosta and Shemesh, 2002] versus 0.02 to 0.035 weight $\%$ when cleaned with perchloric plus hydrochloric acid or peroxide [e.g., Sigman et al., 1999a; Robinson et al., 2004]. Cleaning with a solution containing nitric acid clearly adds $\mathrm{N}$ to these samples over time [e.g., Crosta and Shemesh, 2002, Figure 6a] and may be the cause of this difference in $\mathrm{N}$ content and isotopic composition between the two methods (it should be pointed out, however, that this cleaning method appears to do no damage to the carbon content or isotopic composition of that organic matter). Cleaning at high temperatures may also alter the $\delta^{15} \mathrm{~N}$ of the sample [Robinson et al., 2004].

[33] It is difficult to know when a diatom sample is exactly clean enough for measurement of $\delta^{15} \mathrm{~N}_{\text {diatom. }}$. There is just as much danger of cleaning methods altering or extracting organic matter from the cell wall as there is of cleaning methods failing to fully remove cytoplasm, exudates, and detritus. For $\delta^{15} \mathrm{~N}_{\text {diatom }}$ to be a useful proxy, cleaning methods need to be at least standardized between the labs making the measurements. At best, cleaning methods should be investigated in close conjunction with imaging of organic matter within the silica, and with characterization of its isotopic and chemical composition.

[34] At the moment, little can be said about the impact of these different cleaning methods on measurements of silicon isotopes. Neither nitric, hydrochloric, and perchloric acids nor acidified peroxide utilized, as they are, at temperatures below $65^{\circ} \mathrm{C}$, should cause dissolution or alteration of the silica structure of opal. If there are impacts on $\delta^{30} \mathrm{Si}$ (something which has never been investigated) they would 
most likely be related to the degree to which the different cleaning methods remove any remaining adsorbed clays.

\subsection{Wet Digestion Versus Combustion in an Elemental Analyzer for $\delta^{15} \mathbf{N}_{\text {diatom }}$}

[35] Values of diatom opal $\delta^{15} \mathrm{~N}$ also vary with the method used to convert $\mathrm{N}$ into a gas for isotopic analysis. Combustion of opal samples in a vacuum line produced $\delta^{15} \mathrm{~N}$ values 3 to $6 \%$ higher than for samples combusted in an elemental analyzer (Figure 6) and was quickly abandoned as an analytical method. More recently, wet digestion of the opal has been shown to release only half the amount of $\mathrm{N}$ and yield $\delta^{15} \mathrm{~N}$ values that are between 0 and 3\%o higher than measurements made via an elemental analyzer [Robinson et al., 2004]. The wet-digestion method either avoids contamination from atmospheric $\mathrm{N}_{2}$ adsorbed onto the porous silica, or incompletely reacts the organic material present in the sample.

[36] Given the general paucity of $\delta^{15} \mathrm{~N}_{\text {diatom }}$ measurements by any method, there is not enough data to indicate whether combustion or wet digestion yields the more correct values of $\delta^{15} \mathrm{~N}$, but there is some evidence from $\mathrm{C} / \mathrm{N}$ ratios to suggest that the combustion method is more sound. The main organic components of the diatom cell wall are long chain polyamines [Kröger et al., 1994, 2000] and such material should have a fairly low $\mathrm{C} / \mathrm{N}$ ratio, somewhere around the $4 \mathrm{~mol} \mathrm{~mol}^{-1}$ that is a fairly average value for proteins [Hedges et al., 2002]. The $\mathrm{C} / \mathrm{N}$ ratio of fossil organic matter from diatom silica cleaned without nitric acid and measured by combustion is 5 to $7 \mathrm{~mol} \mathrm{~mol}^{-1}$ [Sigman et al., 1999a]. The amount of $\mathrm{N}$ in these same samples, when measured by wet oxidation [Robinson et al., 2004], is half of that reported for the combustion method [Sigman et al., 1999a], which would increase their $\mathrm{C} / \mathrm{N}$ ratio to 10 to $14 \mathrm{~mol} \mathrm{~mol}^{-1}$. These values are unrealistically high for proteinaceous organic matter and suggest either that the wet-oxidation method is in error or that the combustion technique gives false carbon numbers.

\subsection{Implications of Shifts in $\mathrm{C} / \mathrm{N}$ Ratios for Both $\delta^{15} \mathrm{~N}$ and $\delta^{30} \mathrm{Si}$}

[37] There appears to be sizable variation in the $\mathrm{C} / \mathrm{N}$ ratio of the organic matter of diatom opal [Crosta et al., 2002]. These variations occur in cores that were cleaned with nitric acid; $\mathrm{C} / \mathrm{N}$ ratios in core $\mathrm{SO} 136-111$ range between 3 and $10 \mathrm{~mol} \mathrm{C}(\mathrm{mol} \mathrm{N})^{-1}$ over the last full glacial cycle [Crosta et al., 2002] (Figure 2c). The variations also occur in cores that were not cleaned with nitric acid; in core MD88-769 [Crosta et al., 2005], C/N ranges between 8 and $14 \mathrm{~mol} \mathrm{C}$ $(\mathrm{mol} \mathrm{N})^{-1}$ over the interval between 5 and 30 thousand years ago. A transect of Southern Ocean sediment core tops, also cleaned without nitric acid, yielded $\mathrm{C} / \mathrm{N}$ ratios of 5 to $7 \mathrm{~mol} \mathrm{C}(\mathrm{mol} \mathrm{N})^{-1}$ [Sigman et al., 1999a].

[38] The variability in $\mathrm{C} / \mathrm{N}$, which in some cores mirrors the trend in diatom $\delta^{15} \mathrm{~N}$ (Figure 2) and in some cores does not, for example, MD88-769 in the work of Crosta et al. [2005], is not understood. If the C/N shifts are real and not an artifact of cleaning or combustion, there are several possible causes for them. The composition of the diatom cell wall organic matter may be changing within one given species of diatom over time, with high $\mathrm{C} / \mathrm{N}$ ratios indicating an increase in the nonproteinaceous components of the cell wall. Alternatively, variations may be tied to climatically linked shifts in the species composition of the sediment being analyzed. The cell wall is critical to survival and it seems unlikely that its composition could change as drastically within one single species as it does down core. It also seems unlikely that a change in environmental conditions severe enough to shift the $\mathrm{C} / \mathrm{N}$ of organic matter as critical as that controlling the morphology of the silica cell wall would not have an impact on the diatom species assemblage.

[39] There is no published study of opal isotopes that looks at the relationship between isotopic composition and the species composition of the material analyzed. However, in some cores, extreme values of $\mathrm{C} / \mathrm{N}, \delta^{13} \mathrm{C}$, and $\delta^{15} \mathrm{~N}$ at the LGM that could easily be interpreted as being strictly environmental in origin coincide with the sudden, transient, and marked dominance of the diatom, Eucampia antarctica, in analyzed material (H. Jacot Des Combes, unpublished data, 2005). Given this and marked variations in things like Chaeotoceros resting spores in the sediments [Abelmann et al., 2006], a great possibility exists that some of the shifts in the $\delta^{15} \mathrm{~N}$ of organic matter (or the $\delta^{30} \mathrm{Si}$ of silica) with shifts in oceanographic or climatic conditions may not be due entirely to changes in nutrient utilization. The extent of $\mathrm{N}$ isotope fractionation varies from species to species [Needoba et al., 2003], for example, and with environmental conditions [Needoba and Harrison, 2004]. As a result of these things, the magnitude of the fractionation expressed from region to region is variable, as exemplified by the 2 to $3 \%$ greater degree of $\mathrm{N}$ isotope fractionation associated with nitrate uptake north of the present-day Antarctic Polar Front versus south of it [DiFiore et al., 2006].

[40] In addition to this, not all sedimenting diatoms grow during the spring bloom [Kemp et al., 2000; Abelmann et al., 2006]. This means that a shift in the sedimentary species composition could be tied to a shift the locus of production of the deposited material from a spring bloom conditions to more nutrient depleted conditions of the later summer and cause variations in $\delta^{30} \mathrm{Si}$ or $\delta^{15} \mathrm{~N}_{\text {diatom }}$ that are more nicherelated than related to annual average nutrient draw down. Both the $\mathrm{Si}$ and $\mathrm{N}$ isotopes rely on the assumption that the sedimentary signal contains predominantly diatoms produced during the spring bloom (i.e., major growth phase of the year) and by thus sampling the bulk of the material produced annually, represents a seasonally integrated signal. Seasonally integrated signals, by virtue of being integrated, are confined to a smaller isotopic range than occurs during the water column during the course of a single year. Thus any bias toward the accumulation of opal produced during the end of the season (and having the higher $\delta^{30} \mathrm{Si}$ and $\delta^{15} \mathrm{~N}$ signatures associated with nutrient depletion) will skew the sedimentary signal, and would indicate a greater annual degree of nutrient consumption than had actually been attained.

\subsection{Fluorination Versus MC-ICP-MS Measurements of $\delta^{30} \mathrm{Si}$}

[41] The Si isotopic composition of opal, silicates, and dissolved $\mathrm{Si}$ have traditionally been measured by the 
fluorination of the samples in a vacuum line to produce $\mathrm{SiF}_{4}$ which is then analyzed on a gas source mass spectrometer [Tilles, 1961; Douthitt, 1982; Ding et al., 1996; De La Rocha et al., 1996]. Analyses have also been made via multicollector inductively coupled plasma mass spectrometry (MC-ICP-MS) [De La Rocha, 2002; Cardinal et al., 2003] and secondary ion mass spectrometry (SIMS) [Basile-Doelsch et al., 2005]. These methods avoid the use of fluorinating gases, but the low-resolution MC-ICP-MS methods are hampered by interferences from $\mathrm{N}_{2}, \mathrm{CO}, \mathrm{CHO}$, and $\mathrm{NO}$ on the main masses of interest $(28,29$, and 30$)$, the inability to measure ${ }^{30} \mathrm{Si} /{ }^{28} \mathrm{Si}$ ratios, and the partial loss, with variable fractionation, of $\mathrm{Si}$ through the desolvating nebulizer when samples have been digested in HF. Such difficulties can be overcome by digestion of the sample in strong base, and by the use of MC-ICP-MS machines with high- or pseudo-high-resolution capability (B. Reynolds, personal communication, 2005) via which it is possible to resolve the poly atomic interferences from the Si ion beams.

[42] Although too few common materials have been measured for robust comparison of the different $\mathrm{Si}$ isotope methods to be made at the present time, the methods seem to be yielding complementary values. Analysis of sedimentary diatom opal by fluorination [De La Rocha et al., 1998; Brzezinski et al., 2002] and deep sea sponges by MC-ICPMS [De La Rocha, 2003] both yield values expected given the fractionation factors and $\delta^{30} \mathrm{Si}$ of seawater. The $\delta^{30} \mathrm{Si}$ of marine silicic acid measured by fluorination [De La Rocha et al., 2000a; Varela et al., 2004] and MC-ICP-MS [Cardinal et al., 2005] also fall into similar ranges. Direct comparison of the results from different methods and multiple laboratories is, however, urgently needed.

\subsection{Separation and Sorting of Opal Samples}

[43] The preparation of opal samples for isotopic analysis consists of the separation of biogenic opal from minerals and clays, the isolation of a reasonably homogeneous opal fraction, and the removal of detrital organic matter, clays, and other adsorbed materials [Singer and Shemesh, 1995; Sigman et al., 1999a; Rings et al., 2004]. For marine samples, the separation of diatoms from abiogenic mineral grains is not problematic (volcanic glasses aside) and is carried out by centrifugation of washed and sieved sediments through a heavy liquid.

[44] Isolated opal fractions are then sorted into size fractions (e.g., $>63 \mu \mathrm{m}, 20-63 \mu \mathrm{m},<20 \mu \mathrm{m}$ ) and analyzed. Owing to the irregular shapes and small size of diatoms ( 5 to $50 \mu \mathrm{m}$ in diameter), it is currently impossible to isolate monospecific diatom samples and samples may also contain fragments of radiolarians or volcanic glass. If the speciesspecific isotopic composition of foraminifera is anything to go by (not to mention the variability in $\mathrm{C} / \mathrm{N}$ of sedimentary diatom frustules), separating diatom opal into something more closely resembling monospecific fractions will seriously improve opal-based paleoenvironmental reconstructions. Not only could species-specific fractionation factors be a problem, but so could life history strategies (e.g., sedimentation of vegetative cells produced during spring bloom growth versus the sedimentation of resting spores formed close to nutrient exhaustion).
[45] Progress with sample sorting has been made recently using "split-flow lateral-transport thin fractionation" (SPLITT) cells [Rings et al., 2004]. This method separates particles of varying size, shape, or density in a laminar flow of water between two plates. This technique allows for some sorting of the opal into more specific fractions [Rings et al., 2004]. Small, rare radiolarians can be concentrated out of marine sediment samples, for example, and, to some extent, pennate diatoms can be separated from more centric forms $(\mathrm{H}$. Jacot Des Combes, personal communication, 2005). Further advances in separation techniques will reveal to what extent isotopic shifts seen between the LGM and the Holocene, are related to shifts in species composition rather than environmental changes. In the meantime, archiving slides of cleaned materials analyzed would help to rule in or out species shifts as a major contributor to down core isotope variations.

\section{Conclusions}

[46] The $\delta^{30} \mathrm{Si}$ and $\delta^{15} \mathrm{~N}_{\text {diatom }}$ of diatom opal are the best view we have of nutrient utilization in the past and the balance between $\mathrm{CO}_{2}$ ventilation via upwelling and $\mathrm{CO}_{2}$ drawdown via the biological pump. Modeling work and measurements of the $\delta^{30} \mathrm{Si}$ and $\delta^{15} \mathrm{~N}$ of dissolved nutrients in the water column and the $\delta^{15} \mathrm{~N}_{\text {diatom }}$ of sediment core tops support the use of $\delta^{30} \mathrm{Si}$ and $\delta^{15} \mathrm{~N}_{\text {diatom }}$ as tracers of silicic acid and nitrate utilization, respectively. There are a couple of issues that remain to be resolved about the use of these as paleoceanographic proxies. In principle, secular variations in average marine $\delta^{30} \mathrm{Si}$ could contribute to the observed down core variations in $\delta^{30} \mathrm{Si}$. The existence and size of secular variations could be determined through reconstructions of deepwater $\delta^{30} \mathrm{Si}$ using opal from sponges or deep-dwelling radiolarians. The biggest problem facing $\delta^{15} \mathrm{~N}_{\text {diatom }}$ is the multiplicity of cleaning and analytical methods in use and a general lack of knowledge of how much organic matter a clean diatom frustule should contain and what its $\mathrm{C} / \mathrm{N}$ ratio should be. The considerable variability in the $\mathrm{C} / \mathrm{N}$ of diatom opal over glacial-interglacial cycles further suggests that changes in the species assemblages present in the sediments may be contributing to measured variations in both $\mathrm{N}$ and $\mathrm{Si}$ isotopes. Separations of opal sediments into something more closely resembling monospecific samples is a key development that needs to be made. In the meantime, some information on the species present in each sample as analyzed needs to be collected alongside the isotopic data.

[47] Acknowledgments. Thanks are owed to H. Jacot Des Combes, R. Gersonde, and A. Abelmann for discussions, A. Kemp for advice, D. Wolf-Gladrow and two anonymous reviewers for helpful comments, and D. Sigman and P. DiFiore for promptly sending a preprint. This work was done as a part of EPICA-MIS.

\section{References}

Abelmann, A., R. Gersonde, G. Cortese, G. Kuhn, and V. Smetacek (2006), Extensive phytoplankton blooms in the Atlantic sector of the glacial Southern Ocean, Paleoceanography, 21, PA1013, doi:10.1029/ 2005PA001199.

Altabet, M. A., and R. François (1994), Sedimentary nitrogen isotopic ratio as a recorder for surface nitrate utilization, Global Biogeochem. Cycles, 8 , $103-116$. 
Altabet, M. A., and R. Francois (2001), Nitrogen isotope biogeochemistry of the Antarctic Polar Frontal Zone at $170^{\circ} \mathrm{W}$, Deep Sea Res., Part II, 48 , $4247-4273$

Anderson, R. F., Z. Chase, M. Q. Fleisher, and J. Sachs (2002), The Southern Ocean's biological pump during the Last Glacial Maximum, Deep Sea Res., Part II, 49, 1909-1938.

Barford, C. C., J. P. Montoya, M. A. Altabet, and R. Mitchell (1999), Steady-state nitrogen isotope effects of $\mathrm{N}_{2}$ and $\mathrm{N}_{2} \mathrm{O}$ production in Paracoccus denitirificans, Appl. Environ. Microbiol., 65, 989-994.

Basile-Doelsch, I., J.-D. Meunier, and C. Parron (2005), Another continental pool in the terrestrial silicon cycle, Nature, 433, 399-402.

Brandes, J. A., and A. H. Devol (2002), A global marine fixed nitrogen isotopic budget: Implications for Holocene nitrogen cycling, Global Biogeochem. Cycles, 16(4), 1120, doi:10.1029/2001GB001856.

Brzezinski, M. A., C. J. Pride, V. M. Franck, D. M. Sigman, J. L. Sarmiento, K. Matsumoto, N. Gruber, G. H. Rau, and K. H. Coale (2002), A switch from $\mathrm{Si}(\mathrm{OH})_{4}$ to $\mathrm{NO}_{3}^{-}$depletion in the glacial Southern Ocean, Geophys. Res. Lett., 29(12), 1564, doi:10.1029/2001GL014349.

Cardinal, D., L. Y. Alleman, J. de Jong, K. Ziegler, and L. Andre (2003), Isotopic composition of silicon measured by multicollector plasma source mass spectrometry in dry plasma mode, J. Anal. At. Spectrom., 18, $213-$ 218

Cardinal, D., L. Y. Alleman, F. Dehairs, N. Savoye, T. W. Trull, and L. André (2005), Relevance of silicon isotopes to Si-nutrient utilization and Si-source assessment in Antarctic waters, Global Biogeochem. Cycles, 19, GB2007, doi:10.1029/2004GB002364.

Chase, Z., R. F. Anderson, M. Q. Fleisher, and P. W. Kubik (2003), Accumulation of biogenic and lithogenic material in the Pacific sector of the Southern Ocean during the past 40,000 years, Deep Sea Res., Part II, 50, $799-832$

Crosta, X., and A. Shemesh (2002), Reconciling down core anticorrelation of diatom carbon and nitrogen isotopic ratios from the Southern Ocean, Paleoceanography, 17(1), 1010, doi:10.1029/2000PA000565.

Crosta, X., A. Shemesh, M.-E. Salvignac, H. Gildor, and R. Yam (2002), Late quaternary variations of elemental ratios $(\mathrm{C} / \mathrm{Si}$ and $\mathrm{N} / \mathrm{Si})$ in diatombound organic matter from the Southern Ocean, Deep Sea Res., Part II, 49, $1939-1952$.

Crosta, X., A. Shemesh, J. Eltourneau, R. Yam, I. Billy, and J. J. Pichon (2005), Nutrient cycling in the Indian sector of the Southern Ocean over the last 50,000 years, Global Biogeochem. Cycles, 19, GB3007, doi:10.1029/2004GB002344.

De La Rocha, C. L. (2002), Measurement of variations in silicon stable isotope natural abundances via multi-collector inductively coupled plasma mass spectrometry (MC-ICP-MS), Geochem. Geophys. Geosyst., 3(8), 1045, doi:10.1029/2002GC000310.

De La Rocha, C. L. (2003), Silicon isotope fractionation by marine sponges and the reconstruction of the silicon isotope composition of ancient deep water, Geology, 31, 423-426.

De La Rocha, C. L., and M. J. Bickle (2005), Sensitivity of silicon isotopes to whole-ocean changes in the silica cycle, Mar. Geol., 267, 267-282.

De La Rocha, C. L., M. A. Brzezinski, and M. J. DeNiro (1996), Purification, recovery, and laser-driven fluorination of silicon from dissolved and particulate silica for the measurement of natural stable isotope abundances, Anal. Chem., 68, 3746-3750.

De La Rocha, C. L., M. A. Brzezinski, and M. J. DeNiro (1997), Fractionation of silicon isotopes by marine diatoms during biogenic silica formation, Geochim. Cosmochim. Acta, 61, 5051-5056.

De La Rocha, C. L., M. A. Brzezinski, M. J. DeNiro, and A. Shemesh (1998), Silicon-isotope composition of diatoms as an indicator of pas oceanic change, Nature, 395, 680-683.

De La Rocha, C. L., M. A. Brzezinski, and M. J. DeNiro (2000a), A first look at the distribution of the stable isotopes of silicon in natural waters, Geochim. Cosmochim. Acta, 64, 2467-2477.

De La Rocha, C. L., D. A. Hutchins, M. A. Brzezinski, and Y. Zhang (2000b), Effects of iron and zinc deficiency on elemental composition and silica production by diatoms, Mar. Ecol. Prog. Ser., 195, $71-79$.

Derry, L. A., A. C. Kurtz, K. Ziegler, and O. A. Chadwick (2005), Biological control of terrestrial silica cycling and export fluxes to watersheds, Nature, 433, 728-731.

DiFiore, P., D. M. Sigman, T. W. Trull, M. J. Lourey, K. Karsh, G. Cane, and R. Ho (2006), Nitrogen isotope constraints on subantarctic biogeochemistry, J. Geophys. Res., 111, C08016, doi:10.1029/2005JC003216.

Ding, T., S. Jiang, D. Wan, A. Li, J. Li, H. Song, Z. Liu, and X. Lao (1996), Silicon Isotope Geochemistry, Geol. Publ. House, Beijing.

Ding, T., D. Wan, C. Wang, and F. Zhang (2004), Silicon isotope compositions of dissolved silicon and suspended matter in the Yangze River, China, Geochim. Cosmochim. Acta, 68, 205-216.
Douthitt, C. B. (1982), The geochemistry of the stable isotopes of silicon, Geochim. Cosmochim. Acta, 46, 1449-1458.

Franck, V. M., K. W. Bruland, D. A. Hutchins, and M. A. Brzezinski (2003), Iron and zinc effects on silicic acid and nitrate uptake kinetics in three high-nutrient, low-chlorophyll (HNLC) regions, Mar. Ecol. Prog. Ser. $252,15-33$.

François, R., M. A. Altabet, E.-F. Yu, D. M. Sigman, M. P. Bacon, M. Frank, G. Bohrmann, G. Bareille, and L. D. Labeyrie (1997), Water column stratification in the Southern Ocean contributed to the lowering of glacial atmospheric $\mathrm{CO}_{2}$, Nature, 389, 929-935.

Frank, M., R. Gersonde, M. Rugers van der Loeff, G. Bohrmann, C. C. Nürnberg, P. W. Kubik, M. Suter, and A. Mangini (2000), Similar glacial and interglacial export bioproductivity in the Atlantic sector of the Southern Ocean: Multiproxy evidence and implications for glacial atmospheric $\mathrm{CO}_{2}$, Paleoceanography, 15, 642-658

Hedges, J. I., J. A. Baldock, Y. Gélinas, C. Lee, M. L. Peterson, and S. G. Wakeham (2002), The biochemical and elemental compositions of marine plankton: A NMR perspective, Mar. Chem., 78, 47-63.

Hutchins, D., and K. W. Bruland (1998), Iron-limited growth and Si:N uptake ratios in a coastal upwelling regime, Nature, 393, 561-564.

Kemp, A. E. S., J. Pike, R. B. Pearce, and C. B. Lange (2000), The "fall dump"-A new perspective on the role of a "shade flora" in the annual cycle of diatom production and export flux, Deep Sea Res., Part II, 47, $2129-2154$

Kienast, M. (2000), Unchanged nitrogen isotopic composition of organic matter in the South China Sea during the last climatic cycle: Global implications, Paleoceanography, 15, 244-253.

Knox, F., and M. B. McElroy (1984), Changes in atmospheric $\mathrm{CO}_{2}$ : Influence of the marine biota at high latitude, J. Geophys. Res., 89, 46294637.

Kröger, N., C. Bergsdorf, and M. Sumper (1994), A new calcium binding glycoprotein family constitutes a major diatom cell wall component, EMBO J., 13, 4676-4683

Kröger, N., R. Deutzmann, C. Bergsdorf, and M. Sumper (2000), Speciesspecific polyamines from diatoms control silica morphology, Proc. Natl. Acad. Sci. U. S. A., 97, 14,133-14,138.

Lourey, M. J., T. W. Trull, and D. M. Sigman (2003), Sensitivity of $\delta^{15} \mathrm{~N}$ of nitrate, surface suspended and deep sinking particulate nitrogen to seasonal nitrate depletion in the Southern Ocean, Global Biogeochem. Cycles, 17(3), 1081, doi:10.1029/2002GB001973

Macko, S. A., M. L. Fogel, P. E. Hare, and T. C. Hoering (1987), Isotopic fractionation of nitrogen and carbon in the synthesis of amino acids by microorganisms, Chem. Geol., 65, 79-92.

Mariotti, A., J. C. Germon, P. Hubert, R. Letolle, A. Tardieux, and P. Tardieux (1981), Experimental determination of nitrogen isotope fractionation: Some principles; illustration for the denitrification and nitrification processes, Plant Soil, 62, 413-430.

Milligan, A. J., D. E. Varela, M. A. Brzezinski, and F. M. M. Morel (2004), Dynamics of silicon metabolism and silicon isotopic discrimination in a marine diatom as a function of $\mathrm{pCO}_{2}$, Limnol. Oceanogr., 49, 322329.

Montoya, J. P., and J. J. McCarthy (1995), Isotopic fractionation during nitrate uptake by phytoplankton grown in continuous culture, J. Plankton Res., 17, 439-464.

Needoba, J. A., and P. J. Harrison (2004), Influence of low light and A light: Dark cycle on $\mathrm{NO}_{3}^{-}$uptake, intracellular $\mathrm{NO}_{3}^{-}$and nitrogen isotope fractionation by marine phytoplankton, J. Phycol., 40, 505-516.

Needoba, J. A., N. A. Waser, P. J. Harrison, and S. E. Calvert (2003), Nitrogen isotope fractionation in 12 species of marine phytoplankton during growth on nitrate, Mar. Ecol. Prog. Ser., 255, 81-91.

Rings, A., A. Lücke, and G. H. Schleser (2004), A new method for the quantitative separation of diatom frustules from lake sediments, Limnol. Oceanogr. Methods, 2, 25-34.

Robinson, R. S., B. G. Brunelle, and D. M. Sigman (2004), Revisiting nutrient utilization in the glacial Antarctic: Evidence from a new method for diatom-bound $\mathrm{N}$ isotope analysis, Paleoceanography, 19, PA3001, doi:10.1029/2003PA000996.

Robinson, R. S., D. M. Sigman, P. J. DiFiore, M. M. Rohde, T. A. Mashiotta, and D. W. Lea (2005), Diatom-bound ${ }^{15} \mathrm{~N} /{ }^{14} \mathrm{~N}$ : New support for enhanced nutrient consumption in the ice age subantarctic, Paleoceanography, 20 , PA3003, doi:10.1029/2004PA001114.

Saino, T., and A. Hattori (1980), ${ }^{15} \mathrm{~N}$ natural abundance in oceanic suspended particulate matter, Nature, 283, 752-754.

Sarmiento, J. L., and J. R. Toggweiler (1984), A new model for the role of the oceans in determining atmospheric $\mathrm{PCO}_{2}$, Nature, 308, 621-624.

Sarmiento, J. L., N. Gruber, M. A. Brzezinski, and J. P. Dunner (2004), High-latitude controls of thermocline nutrients and low latitude biological productivity, Nature, 427, 56-60. 
Schneider-Mor, A., R. Yam, C. Bianchi, M. Kunz-Pirrung, R. Gersonde, and A. Shemesh (2005), Diatom stable isotopes, sea ice presence and sea surface temperature records of the past $640 \mathrm{ka}$ in the Atlantic sector of the Southern Ocean, Geophys. Res. Lett., 32, L10704, doi:10.1029 2005GL022543.

Shackleton, N. J., J. D. H. Wiseman, and H. A. Buckley (1973), Nonequilibrium isotope fractionation between seawater and planktonic foraminiferal tests, Nature, 242, 177-179.

Shemesh, A., S. A. Macko, C. D. Charles, and G. H. Rau (1993), Isotopic evidence from reduced productivity in the glacial Southern Ocean, Science, 262, 407-410.

Shemesh, A., D. Hodell, X. Crosta, S. Kanfoush, C. Charles, and T. Guilderson (2002), Sequence of events during the last deglaciation in Southern Ocean sediments and Antarctic ice cores, Paleoceanography, 17(4), 1056, doi:10.1029/2000PA000599.

Siegenthaler, U., and T. Wenk (1984), Rapid atmospheric $\mathrm{CO}_{2}$ variations and ocean circulation, Nature, 308, 624-626.

Sigman, D. M., and E. A. Boyle (2000), Glacial/interglacial variations in atmospheric carbon dioxide, Nature, 407, 859-869.

Sigman, D. M., M. A. Altabet, R. François, D. C. McCorkle, and J.-F. Gaillard (1999a), The isotopic composition of diatom-bound nitrogen in Southern Ocean sediments, Paleoceanography, 14, 118-134.

Sigman, D. M., M. A. Altabet, D. C. McCorkle, R. Francois, and G. Fischer (1999b), The $\delta^{15} \mathrm{~N}$ of nitrate in the Southern Ocean: Consumption of nitrate in surface waters, Global Biogeochem. Cycles, 13, 1149-1166.

Singer, A. J. (1994), Diatom ${ }^{13} \mathrm{C}$ records from Southern Ocean sediments: Glacial-interglacial variation in surface water characteristics, M.S. thesis, Weizmann Inst. of Sci., Rehovot, Israel.
Singer, A. J., and A. Shemesh (1995), Climatically linked carbon isotope variation during the past 430,000 years in Southern Ocean sediments, Paleoceanography, 10, 171-177.

Spero, H. J., and D. W. Lea (1996), Experimental determination of stable isotope variability in Globigerina bulloides: Implications for paleoceanographic reconstructions, Mar. Micropaleontol., 28, 231-246.

Takeda, S. (1998), Influence of iron availability on nutrient consumption ratio of diatoms in oceanic waters, Nature, 393, 774-777.

Tilles, D. (1961), Natural variations in isotopic abundances of silicon, J. Geophys. Res., 66, 3003-3014.

Tréguer, P., D. M. Nelson, A. J. Van Bennekom, D. J. DeMaster, A. Leynaert, and B. Quéguiner (1995), The silica balance in the world ocean: A reestimate, Science, 268, 375-379.

Varela, D. E., C. J. Pride, and M. A. Brzezinski (2004), Biological fractionation of silicon isotopes in Southern Ocean surface waters, Global Biogeochem. Cycles, 18, GB1047, doi:10.1029/2003GB002140.

Wischmeyer, A. G., C. L. De La Rocha, E. Maier-Reimer, and D. A Wolf-Gladrow (2003), Control mechanisms for the oceanic distribution of silicon isotopes, Global Biogeochem. Cycles, 17(3), 1083, doi:10.1029/2002GB002022.

Ziegler, K., O. A. Chadwick, M. A. Brzezinski, and E. F. Kelly (2005), Natural variations of $\delta^{30} \mathrm{Si}$ ratios during progressive basalt weathering, Hawaiian Islands, Geochim. Cosmochim. Acta, 69, 4597-4610.

C. L. De La Rocha, Alfred-Wegener-Institut für Polar und Meeresforschung, Columbusstrasse, D-27568 Bermerhaven, Germany. (crocha@ awi-bremerhaven.de) 